Article

\title{
Students' Academic Use of Mobile Technology and Higher-Order Thinking Skills: The Role of Active Engagement
}

\author{
Hye Jeong Kim ${ }^{1}$, Pilnam Yi ${ }^{2, *}$ and Ji In Hong ${ }^{2}$ \\ 1 Graduate School of Education, Chung-Ang University, Seoul 06974, Korea; hyejeongkim@cau.ac.kr \\ 2 Department of Education, Hongik University, Seoul 04066, Korea; 9199hong@daum.net \\ * Correspondence: pilnamyi@hongik.ac.kr
}

Received: 17 January 2020; Accepted: 23 February 2020; Published: 25 February 2020

check for updates

\begin{abstract}
The academic use of mobile technology engages students beyond traditional classroom contexts. Over the past few years, higher education institutions have promoted students' learning and growth by supporting their use of mobile technology. Mobile technology offers educational possibilities that can enhance students' growth in higher education. The aim of this study is to examine the relationship between college students' academic use of mobile technology and higher-order thinking skills through their active engagement and learning effort. The sample consisted of 456 students at a university in South Korea, and the data were analyzed using partial least squares structural equation modeling. The results suggest that the academic use of mobile technology influences students' higher-order thinking skills directly, in addition to their learning effort and active engagement in courses. These findings provide valuable information for higher education institutions that seek to introduce interactive and technology-integrated environments.
\end{abstract}

Keywords: mobile technology; active engagement; learning effort; higher-order thinking skills

\section{Introduction}

The ubiquity of digital technology in our daily life implies that the digital generation is growing up and entering schools and workplaces in a digitally rich environment. Technology has gradually become an ever-present part of student life in today's networked society [1-3]. The current young generation, with access to educational activities at any time and place, may be developing different ways of learning through the ubiquitous digital technologies that are central to everyday functioning at school, at home, and in the community [4,5]. This generation uses these technologies to interact with others, absorb information from multiple sources, engage in content creation, share information and views, acquire knowledge from online learning and open-access educational resources, and study in personalized learning environments using hand-held devices [6,7]. The potential for using digital technology in higher education builds upon various learning experiences $[8,9]$.

In the ecosystem of the digitally rich campus environment, students' academic use of mobile technology has grown exponentially in the last decade [10]. The entire education community seems to be firmly in the grip of mobile devices, and these are increasingly providing a personal platform that facilitates a linkage with the world. The empowerment of individuals with mobile technology enhances students' preferences regarding the content and processes of traditional and student-centered learning approaches [11,12]. Various learner preferences and needs can be supported by the ever-present and multifunctional features of mobile technology, which make it possible to personalize learning experiences and effectively interact with others [13].

Students' use of mobile technology can contribute to active experiences both inside and outside the classroom. Mobile technology for individual students has changed the meaning of learning in and 
out of the classroom, infusing learning experiences with more active and interactive tasks [14]. This includes searching for information, actively communicating with instructors in a large class, learning using more interactive information, sharing opinions or work with others, engaging in content creation, and designing a more customized setting [15]. Although students' technology use has demonstrated inconsistent results regarding academic outcomes [5,16], mobile technology offers a wide range of educational possibilities that can enhance students' growth in higher education. Students' use of mobile technology for academic purposes can create meaningful opportunities in various scenarios, such as student-centered learning, personalized learning, differentiated instructions, and collaboration [17,18]. Mobile technology can also facilitate active participation and interaction in class [19], active exploratory learning [20], application of knowledge, academic performance [21], and attitudes and self-efficacy [22].

One of the educational objectives of higher education institutions is enhancing students' higher-order thinking skills through teaching and learning to prepare them for the society of tomorrow [23]. The ability to analyze, evaluate, and create are considered upper-level skills [24] and are valued in preparing students for their future careers and advanced academic work [25]. Though the use of mobile technology tends to focus on improving students' performance in subjects, their higher-order thinking skills have rarely been extensively examined [2]. It is uncertain if identifying antecedents will enhance research on meaningful links between students' mobile technology use and higher-order thinking skills, rather than surface thinking skills (e.g., memorization, recall, and comprehension of information), in higher education contexts. In this study, we explore the relationship between students' academic use of technology and their higher-order thinking skills as academic outcomes, focusing on the role of students' active engagement and learning effort in the higher education context.

\section{Literature Review}

\subsection{Students' Personal and Academic Use of Technology}

Students' daily use of digital technology has increased the need for personalization and diversity to meet their learning needs in a university setting [26]. They tend to access information, entertain, and interact with others actively [27]. For example, using mobile phones, they download and listen to music, purchase and sell online, constantly connect and socialize via social networks, read and create digital content to share online, and access banking services. Mobile devices are increasingly becoming universal tools and creating opportunities for students. Students are comfortable with using digital technology and adopt new technology quickly and effortlessly.

Unlike young people's use of digital technology in their daily lives, whether they effectively use technology for academic purposes in the higher education context is unknown [5]. Studies report that college students ineffectively incorporate digital technology into their academic experiences and that its use is not associated with academic literacy [28]. To incorporate digital technology meaningfully and effectively for academic purposes, it is necessary to enhance students' digital skills. This can be done through interacting with others for educational purposes, managing information in digital formats, and digitally retrieving useful and relevant information in daily life and training programs [27]. College students have to use technology in university courses to increase their technological competency [29]. Thus, instructors need to actively integrate digital technology as part of their teaching processes as well as provide advanced experiences with digital technology in learning. With support from instructors, students need to invest time in studying using digital technology. This way, incorporating digital technology into the pedagogical approach can enhance students' digital skills, which can impact academic performance at university [30]. The personal use of digital technology counteracts academic outcomes and does not contribute to developing digital technology skills.

\subsection{Engaging in Higher-Order Thinking Skills with Technology}

Recently, higher education institutions have made efforts to provide active learning environments through technology integration. The aim is to improve students' higher-order thinking skills [31,32]. 
An active learning context that incorporates technology can make them self-directed learners. Students can be involved in the learning process, develop higher-order thinking skills such as analyzing and synthesizing ideas, make judgments, and apply theories [33,34].

University education can be regarded as successful if it teaches students to reason in context, assimilate and evaluate multiple sources of evidence, and apply these skills to solve difficult real-life problems through complex thinking [35]. Students' learning is not reliably measured by college GPA [36]. However, students' perception of higher-order thinking skills indicates how much they have learned and changed through their college experiences [37]. Scholars agree that real learning occurs when students are committed to understanding materials using various strategies such as reading widely, combining multiple resources, discussing with others, reflecting on how information relates to larger patterns, and applying knowledge in real-life contexts and situations [38]. Deep learning is positively and strongly associated with cognitive development, particularly higher-order thinking $[31,39]$. Hence, there are concerns regarding which methods should be applied to enhance students' higher-order thinking skills. Higher education institutions focus on deep learning instead of surface learning and use strategies such as rote memorization and reproduction [31]. University education tends to pursue the development of higher-order thinking skills via advanced education, preparing students for the demands of the society of tomorrow [23].

To actively perceive their own higher-order thinking skills, students should be fully engaged in active learning environments in higher education. During higher education, students have to acquire discipline-specific knowledge, higher-order thinking skills, and practical and social skills [40]. This is made possible by members of the university and faculty who are responsible for providing students with educational environments and opportunities to engage in learning both inside and outside of class [40]. The question: how can students be actively engaged in learning to experience growth? University staff should engage students at a higher level of academic effort to challenge their higher-order cognitive processes. These activities can be integrated with appropriate technology for educational experiences [32]. Students' level of engagement in learning experiences is widely accepted to be directly correlated to their academic success.

Researchers have studied how instructional practices with technology impact student engagement and outcomes in higher education. Most studies regard students' use of technology and their consequent positive academic outcomes as an experimental phase. Instructors tend to provide well-designed instructions and actively adopt strategies that integrate technology to facilitate students' motivation and learning (e.g., [41,42]). A well-planned instructional approach that integrates technology helps students be engaged, perform well, and ultimately achieve success. The use of technology in advanced learning experiences (e.g., discussions, reasoning, problem solving, creating, and scaffolding activities) can be considered to facilitate students' advanced cognitive development. However, the simple technological approach does not meaningfully predict or explain how well the integration of technology correlates with positive learning outcomes. This complicates understanding of the association between the use of technology and academic outcomes.

\section{Hypothesis Development}

This section discusses the research model and hypotheses. To investigate the enabling effects of technology in courses on undergraduate students' learning outcomes (i.e., higher-order thinking skills), the research model is formulated based on the aforementioned discussion and prior research on integrating technology into students' learning. Our model suggests that the academic use of digital technology may influence higher-order thinking skills through students' academic effort and active engagement in class.

\subsection{Higher-Order Thinking Skills}

Typically, higher-order thinking requires more cognitive processing than other types of thinking. This concept is used in learning taxonomy (e.g., Bloom's Taxonomy) to understand types of thinking 
skills from the knowledge level to the evaluation level through cognitive processing [43]. For example, Bloom's taxonomy of cognitive domain recognizes the ability to analyze, evaluate, and create as upper-level skills [24]. Lower-level thinking is considered to include memorization, recall, and comprehension of information. Higher-order thinking skills include creative and critical thinking and problem solving [25]. Recently, these skills have been acknowledged as essential for preparing students for their future careers and advanced academic work [25]. Although various definitions and factor structures of higher-order thinking skills abound, Tendhar, Culver, and Burge [44] posited that the factor structure for higher-order thinking skills includes analysis, synthesis, application, and evaluation, which help capture the perceived experiences of students in the university context.

Students need to develop higher-order thinking skills to function effectively, both academically and career-wise. Various learning outcomes (e.g., GPA, retention, personal and social development) are more associated with higher-order thinking strategies than with traditional learning approaches such as surface learning $[31,38,45,46]$. Students are expected to demonstrate learning and perform impressively as evidence of their success at the university level. Researchers have studied the effective measurement of students' success in higher education and examined the potential use of higher-order thinking skills $[47,48]$. Undergraduate students are expected to attend all course activities to understand subject matter content, develop their cognitive and metacognitive skills, and learn higher-order cognitive processes. Some studies also report that higher-order thinking skills, as academic outcomes in higher education, can make a difference in terms of college education environments. For example, first-year college students often face difficulty with higher-order thinking skills, and students in large groups rarely have the opportunity to employ these skills [49]. These findings indicate differences in students' higher-order thinking skills through their learning effort and active engagement [31]. Thus, it is important to examine the active engagement and academic effort of students to determine the impact of higher-order thinking skills.

\subsection{Academic Use of Mobile Technology}

The academic use of technology refers to the way students adopt technology for academic purposes. The growing interest in using personal digital technology in higher education has created a new field of discussion about its impact on students' pedagogical activities [14]. Technology and the latest advancements in it have become inescapable. A particularly noticeable change in student use of technology has ensued: Undergraduate students have decreased the use of desktop computers in favor of personal technology, such as laptops, tablets, and smartphones, and their ownership of hand-held mobile devices has increased due to the development of universal technology. This phenomenon can be explained through the bring your own device (BYOD) model, which refers to students bringing their own personal device to school to engage in learning [50]. Students can remain online constantly to access information anytime and anywhere [5]. Mobile technology's multifunctionality increases the potential for diverse types of teaching and learning and various learning scenarios [51].

Students' academic use of mobile devices facilitates their affective aspects [51]. Their use of technology increases their participation rates in classrooms, interest in learning, and motivation to perform $[5,52]$. Undergraduate students can use mobile technology to access university services, apps, and websites to view their academic progress, course information, and other institutional services (e.g., checking grades, viewing courses/syllabi, entering course/learning management systems, or accessing library resources). Students can also use mobile technology to engage in active learning-such as through classroom interaction using a game-based student response system [53], personalized learning with various apps, and collaborative activities using communication tools or information sharing tools [50]. Students who use technology for academic purposes tend to demonstrate better academic outcomes. The use of technology has also contributed to their literacy and information processing skills [54]. Research has examined the relationship between academic technology use and academic outcomes. Recent students have reported that the personal use of digital devices for academic purposes has exponentially increased. Therefore, we hypothesize the following: 
Hypothesis 1 (H1). Academic use of mobile technology (AM) positively affects active engagement in courses $(A E)$.

Hypothesis 2 (H2). Academic use of mobile technology (AM) positively affects higher-order thinking skills (HS).

Hypothesis 3 (H3). Academic use of mobile technology (AM) positively affects learning effort (LE).

\subsection{Active Engagement in Courses}

Active engagement in courses implies that students invest energy in their learning processes in class activities, thus rendering it a meaningful process for them involving academic learning activities. To be actively engaged in courses, students should perform active learning in courses with learning strategies such as experiential learning, learning by doing, peer tutoring, laboratory work, and technology-integrated learning activities (e.g., simulation, game, or using mobile devices) [55]. These actively engaging learning activities in courses demands higher-order thinking skills from learners.

Students' active engagement in learning includes psychological and behavioral engagement through constructivist methods of learning [55-59], such as efforts made for study, higher-order thinking skills, and participation in educationally effective practices. Higher-order thinking skills are not enhanced automatically; instead, students need to be engaged in educational activities for these skills to improve [60]. Engagement indicates the extent to which students are actively involved in educational activities that are likely to lead to high-quality learning [40]. For students to develop higher-order cognitive processes through engagement in course activities, they need to be highly participative and make substantial effort in learning [61]. We consider active engagement in courses (AE) useful in the relationship between the use of technology and higher-order thinking skills. Therefore, we hypothesize the following:

Hypothesis 4 (H4). Active engagement in courses (AE) positively affects students' higher-order thinking skills (HS).

Hypothesis 5 (H5). Active engagement in courses (AE) positively affects students' learning effort (LE).

\subsection{Learning Effort}

Learning effort is considered an important prerequisite for students' successful learning. Learning effort refers to a learner's willingness to commit to demanding situations before initiating learning actions, and it acts as a link between the motivational and cognitive aspects of learning [62]. Research shows a strong association between learning effort and academic outcomes (e.g., [58,59,62-65]). Schuman et al. [59] and Rau and Durand [58] provided evidence of the relationship between the amount of students' effort and the improvement in their academic outcomes. Franklin [63] found that the quality of college students' effort in academic pursuits positively influences learning and student perceptions of higher-order thinking skills. Learning effort has been examined as a potential predictor of higher-order thinking skills. However, learning effort, measured by study time, significantly influences academic outcomes only in limited conditions, because students' academic outcomes are jointly determined by multiple factors such as class attendance, study environment, scholastic aptitude, previously acquired knowledge and skills, individual abilities, and instructional resources [66]. The development of students' higher-order thinking skills as a learning outcome may be directly influenced by learning effort, which indicates the overall time spent on pre-course preparation, review, and on pre-course preparation and review. Therefore, we hypothesize the following:

Hypothesis 6 (H6). Learning effort (LE) positively affects higher-order thinking skills (HS). 
Based on the previous hypotheses, we develop the research model shown in Figure 1.

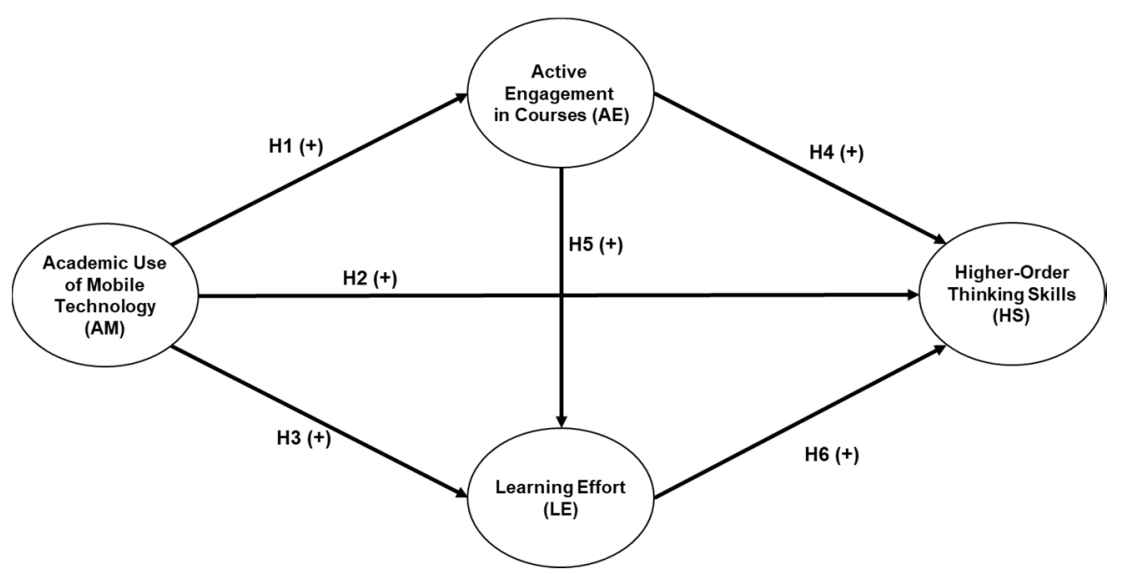

Figure 1. The proposed research model.

\section{Data Collection and Measurements}

\subsection{Procedures and Sample}

An online survey design was applied to collect data. A sample was recruited from a private university in a metropolitan area of South Korea. The students were asked to click a link in the e-mail, which led to the online questionnaire. The respondents were allowed to withdraw participation at any time during the process of filling out the online survey. The data in the study were collected as part of a larger study focusing on the quality of undergraduate education. The students voluntarily participated in the study.

Finally, we collected 456 valid responses. For the study, we used subjects who had personal technology (e.g., smartphones or tablets). Of the subjects, 306 (67.1\%) were male, and $150(32.9 \%)$ were female. In the sample, 30.9\% ( $n=141)$ were freshman, 20.2\% ( $n=92)$ were sophomore, $18.9 \%(n=86)$ were junior, and $30.0 \%(n=137)$ were senior. Students were engaged in different academic disciplines: $16.2 \%$ studied humanities $(n=74) ; 20.2 \%$ social sciences $(n=92) ; 14.5 \%$ natural sciences $(n=66) ; 48.9 \%$ engineering $(n=223)$; and $0.2 \%$ others $(n=1)$.

\subsection{Measures}

An online survey was developed to measure the variables in the larger study. The survey consisted of four subsections including background, student engagement, characterization of school, and technology use. For the current study, we adapted items from the two sections on background and technology use. We used the survey to gather demographic information, frequency of using technology for courses, increasing level of higher-order thinking skills, higher-order thinking skills, and student academic effort as variables of interest.

\subsubsection{Academic Use of Mobile Technology}

Participants were asked to answer a question: "How frequently did you use mobile technology (e.g., smartphone, iPad, or Galaxy Tab) during the last academic year? This related to 8 items: (1) searching for information related to content in courses; (2) creating a memo after reading materials; (3) preparing a presentation; (4) using files in cloud storage; (5) note-taking for study purposes; (6) communicating with instructors (e.g., taking quizzes, submitting opinions); (7) sharing information or materials; and (8) collaborating (e.g., Google docs). The eight items were developed through a review of the existing literature $[67,68]$. Participants responded using a 4-point Likert-type scale, as follows: $1=$ never, 2 = seldom, $3=$ occasionally, and $4=$ frequently. 


\subsubsection{Learning Effort}

Student academic effort involves the effort students expend toward their academic work or academic performance. Study hours (average) for coursework, as an indicator of student effort, is a good predictor of students' academic performance [64]. To examine the academic effort of college students, participants were asked to report the number of hours they studied per week for all their classes. Two variables were the number of average hours studied per week before and after each week. The items measuring study hours were the following: (a) "How many hours per week do you usually study before courses?" and (b) "How many hours per week do you usually study after courses?" Response options ranged from 0 (0 h), 1 (1-5 h), 2 (6-10 h), etc. up through 8 (greater than $30 \mathrm{~h}$ per week).

\subsubsection{Active Engagement in Courses}

To measure the active engagement in courses, we adopted four items from the NSSE instrument [69] regarding one of the benchmarks, that is active and collaborative learning. This examines the extent of students' class participation and the degree to which they have collaborated with other students inside and outside of class. Based on factor analysis, we adopted four items from the original seven-item scale of the original benchmarks. The items asked about the frequency of (1) asking questions in class or contributing to class discussion, (2) presenting a class, (3) working with other students on projects during class and (4) outside of class.

\subsubsection{Higher-Order Thinking Skills}

In terms of higher-order thinking skills, we adopted four items, namely analyzing, synthesizing, applying, and making judgments, from the National Society for the Study of Education [69]. The items addressed students' engagement levels in deep learning. The primary question asked the following: "To what extent did your deep learning (analyzing, synthesizing and organizing, applying, and making judgments) increase by participation in courses in last academic year?" The four deep learning traits being examined were as follows: (1) analyzing an idea, experience, or theory; (2) synthesizing and organizing ideas, information, or experiences; (3) applying theories or concepts to practical problems or new situations; and (4) making judgments about the value or soundness of information or arguments.

\subsection{Statistical Analysis}

Partial least squares-structural equation modeling (PLS-SEM) has become a key technique for data analysis. PLS-SEM is a type of structural equation model used to analyze and measure constructs with multiple observed variables [70,71]. It involves a regression-based ordinary least squares estimation method instead of the maximum likelihood estimation used in SEM [72]. PLS-SEM is effective when used for exploratory research and theory development with fewer data assumptions, such as multivariate normality, smaller sample sizes, and measurement scales [72]. The statistical analysis for this study was conducted using SmartPLS 3.2.7 to assess structural models [73]. SPSS 25.0 was used to examine descriptive statistics of the data. We used a two-step approach suggested by Chin $[70,74]$ to evaluate model fit. We adapted Chin's [70] criteria to examine partial model structures.

\section{Data Analysis}

\subsection{Measurement Model}

To evaluate model fit, we examined the construct validity of the measurement model through assessing discriminant validity and reliability. In the study, the measurement model was assessed in terms of factor loadings of each item, internal consistency reliability, convergent validity, and discriminant validity; see Table 1. Internal consistency reliability was tested and should be higher than $0.70[70,75]$. We examined convergent validity (average variance extracted [AVE, cutoff score 
0.5] and discriminant validity [square-root AVE > correlation]). All items in the measurement model were significant on their construct $(p<0.05)$ and exceeded the minimum threshold of 0.4 , as is recommended [76]. All multi-item constructs met the guidelines for a composite reliability greater than 0.70 and a Cronbach's alpha greater than 0.70 [74]. In Table 2, correlations between constructs are examined. Convergent validity was evaluated using AVE $(>0.50)$ and greater than that construct's correlation with other constructs. All multi-item constructs met the guideline for AVE to be greater than $0.50[72,77]$, which means $50 \%$ or more variance of the indicators was accounted for. All latent constructs satisfied this condition. In the measurement of discriminant validity, the correlations between constructs should be lower than their own extracted variance explanations. The average variance extracted (AVE) and cross-loading can be used to evaluate validity [78]. The square root of the AVE of a construct should be larger than the correlation coefficients between the construct and any other construct in the model [70,79]. All diagonal values exceed the inter-construct correlation. The discriminant and convergent validities of the multi-item constructs of the models were thus acceptable. All results support the reliability and validity of the measurement model.

Table 1. Descriptive results and results for convergent validity for the measurement model.

\begin{tabular}{|c|c|c|c|c|c|c|}
\hline Construct Item & $\mathbf{M}$ & SD & $\begin{array}{c}\text { Factor } \\
\text { Loading }\end{array}$ & $\begin{array}{c}\text { Cronbach's } \\
\text { Alpha }\end{array}$ & $\begin{array}{l}\text { Composite } \\
\text { Reliability }\end{array}$ & AVE \\
\hline Academic use of mobile technology (AP) & & & & 0.86 & 0.89 & 0.51 \\
\hline Information search & 3.04 & 0.88 & 0.69 & & & \\
\hline Making memo after reading materials & 2.55 & 1.00 & 0.75 & & & \\
\hline Preparing a presentation & 2.41 & 1.04 & 0.78 & & & \\
\hline Using materials in cloud services & 2.02 & 1.07 & 0.63 & & & \\
\hline Note-taking for study purposes & 1.89 & 0.99 & 0.70 & & & \\
\hline Communicating with instructors & 1.95 & 0.97 & 0.76 & & & \\
\hline Sharing materials or documents & 2.50 & 1.03 & 0.75 & & & \\
\hline Collaborating & 1.77 & 0.95 & 0.64 & & & \\
\hline Active engagement in courses (AE) & & & & 0.81 & 0.88 & 0.64 \\
\hline Questions or discussions & 2.41 & 0.83 & 0.77 & & & \\
\hline Class presentation & 2.66 & 0.80 & 0.84 & & & \\
\hline Worked with other students in class & 2.86 & 0.80 & 0.84 & & & \\
\hline Worked with classmates outside of class & 2.86 & 0.84 & 0.74 & & & \\
\hline Learning effort (LE) & & & & 0.79 & 0.90 & 0.82 \\
\hline Hours preparing for class & 3.07 & 1.74 & 0.92 & & & \\
\hline Hours reviewing after class & 2.33 & 1.49 & 0.89 & & & \\
\hline Higher-order thinking skills (HS) & & & & 0.82 & 0.88 & 0.65 \\
\hline Increased analyzing skills & 2.72 & 0.78 & 0.76 & & & \\
\hline Increased synthesizing & 2.63 & 0.81 & 0.89 & & & \\
\hline Increased judgment skills & 2.54 & 0.81 & 0.78 & & & \\
\hline Increased application & 2.63 & 0.78 & 0.80 & & & \\
\hline
\end{tabular}

Note. AVE = average variance extracted.

Table 2. Discriminant validity of the measurement model.

\begin{tabular}{ccccc}
\hline Construct & AM & AE & LE & HS \\
\hline Academic use of mobile technology (AM) & 0.715 & & & \\
Active engagement in courses (AE) & 0.425 & 0.798 & & \\
Learning effort (LE) & 0.025 & 0.145 & 0.907 & \\
Higher-order thinking skills (HS) & 0.260 & 0.358 & 0.247 & 0.806 \\
\hline
\end{tabular}

Note. The shaded numbers in the diagonal row are the square root of the AVE for each construct.

\subsection{Structural Model}

Through the measurement model validation, this study subsequently evaluated the structural model to confirm the relationships among constructs and proceeded to test the hypotheses. We used 
the bootstrap re-sampling procedure with 5000 samples [73,77]. The results of the data analysis are presented in Table 3.

The results in Table 3 highlight the effect of academic use of mobile technology (AM) on active engagement in courses (AE) and higher-order thinking skills (HS) with path coefficients of 0.425 (H1, $p<0.001)$ and $0.141(\mathrm{H} 2, p<0.01)$, respectively. Academic use of mobile technology (AM) has no significant effect on learning effort (LE); even though we hypothesize the negative relationship between two factors, only marginal effect exists. Thus, H3 is rejected. This indicates that students' academic use of personal technology did not increase their study hours; otherwise, it is possible to enhance the efficiency of learning through academic use of personal technology. As proposed, active engagement in courses (AE) positively influences higher-order thinking skills (H4, $\beta=0.268, p<0.001)$ and learning effort $(\mathrm{H} 5, \beta=0.164, p<0.01)$. Academic effort was found to have a positive effect on higher-order thinking skills $(\mathrm{H} 6, \beta=0.205, p<0.001)$.

Table 3. Hypotheses, path coefficients, and results.

\begin{tabular}{cccccc}
\hline Hypothesis & Path & $\begin{array}{c}\text { Path } \\
\text { Coefficient }\end{array}$ & T-Statistics & Sig. & $\begin{array}{c}\text { Empirical } \\
\text { Conclusions }\end{array}$ \\
\hline $\mathrm{H} 1$ & $\mathrm{AM} \rightarrow \mathrm{AE}$ & 0.425 & 10.719 & $* * *$ & support \\
$\mathrm{H} 2$ & $\mathrm{AM} \rightarrow \mathrm{HS}$ & 0.141 & 2.668 & $* *$ & support \\
$\mathrm{H} 3$ & $\mathrm{AM} \rightarrow \mathrm{LE}$ & -0.045 & 0.782 & $\mathrm{NS}$ & not supported \\
$\mathrm{H} 4$ & $\mathrm{AE} \rightarrow \mathrm{HS}$ & 0.268 & 5.420 & $* * *$ & support \\
$\mathrm{H} 5$ & $\mathrm{AE} \rightarrow \mathrm{LE}$ & 0.164 & 2.892 & $* *$ & support \\
$\mathrm{H} 6$ & $\mathrm{LE} \rightarrow \mathrm{HS}$ & 0.205 & 2.668 & $* * *$ & support \\
\hline
\end{tabular}

Note. $\mathrm{AM}=$ Academic use of mobile technology, $\mathrm{AE}=$ Active engagement in courses, $\mathrm{HS}=$ Higher-order thinking skills, LE = Learning effort; ${ }^{* *} p<0.01,{ }^{* * *} p<0.00, \mathrm{NS}=$ Nonsignificant.

PLS-SEM provides no global goodness-of-fit indices to examine the adequacy of models [74]. The structural model was assessed by evaluating the structural paths, $\mathrm{t}$-statistics, and variance explained $\left(R^{2}\right)$ [80]. Henseler et al. [74] suggest using the coefficient of determination $\left(R^{2}\right)$ of the endogenous variables as the essential criterion for structural model testing. The final dependent construct, higher-order thinking skills (HS), had an $R^{2}$ value of 0.178 . Additionally, other constructs also had $R^{2}$ values for the following: Active engagement in courses $(\mathrm{AE}=0.179)$ and learning effort (LE=0.018), Figure 2.

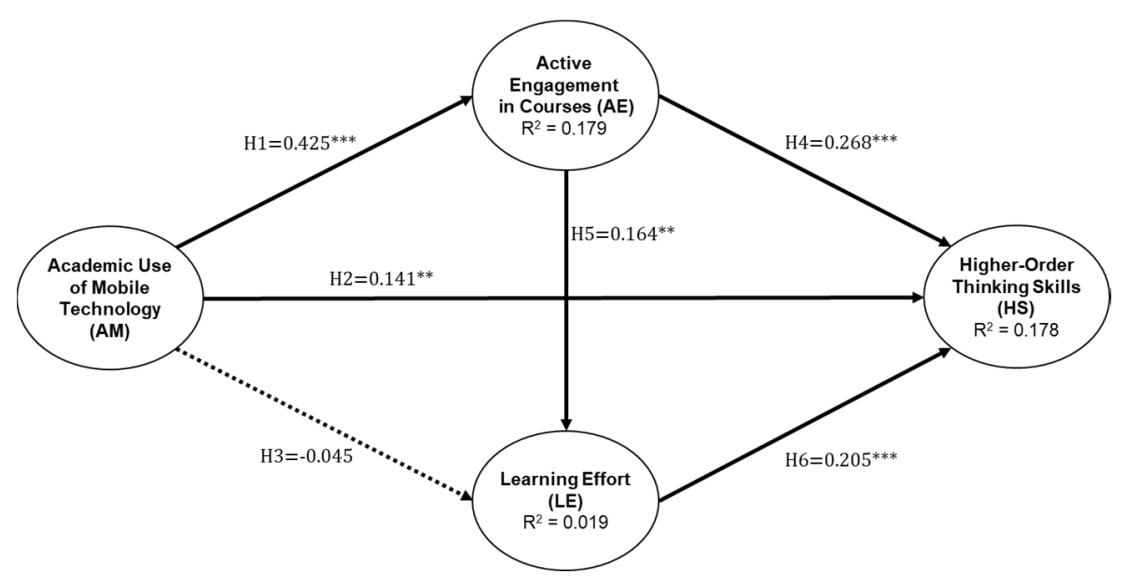

Figure 2. Standardized regression and adjusted R-square for the structural model.

In addition, we assessed the structural model using the effect sizes $f^{2}$, that is the change in the value of $R^{2}$ when an exogenous variable on endogenous variable is removed from the model. Academic use of personal technology has a medium effect size of 0.221 on Active Engagement in Courses (AE), 0.020 on Higher-Order Thinking Skills (HS), and 0.002 on Learning Effort. Active 
Engagement in Courses has a small effect size of 0.023 on Learning Effort and 0.071 on Higher-Order Thinking Skills. To examine the influencing mechanisms of academic use of technology on higher-order thinking skills, we examined the mediation effect of active engagement and learning effort, shown in Table 4 . We adopted the bootstrapping method (5000 samples) to perform the mediation analysis in the PLS-SEM [81,82], bias-corrected confidence estimates [83], and a 95\% confidence interval of the indirect effects. We examined the mediation effects of active engagement in courses between academic use of mobile technology and higher-order thinking skills. As shown in Table 3, active engagement in courses mediated the effect of academic use of mobile technology on higher-order thinking skills and learning effect, except on learning effort.

Table 4. Mediation effects (bootstrapping 5000 samples).

\begin{tabular}{cccccc}
\hline Mediation Path & Effect & T-Statistics & $p$-Value & $\begin{array}{c}\text { 95\% Bias-Corrected } \\
\text { Confidence Interval }\end{array}$ & $\begin{array}{c}\text { Mediation } \\
\text { Effect }\end{array}$ \\
\hline $\mathrm{AM} \rightarrow \mathrm{AE} \rightarrow \mathrm{HS}$ & 0.114 & 5.066 & 0.000 & LLCI: 0.071, ULCI: 0.160 & Yes \\
$\mathrm{AM} \rightarrow \mathrm{AE} \rightarrow \mathrm{LE} \rightarrow \mathrm{HS}$ & 0.014 & 2.170 & 0.027 & LLCI: 0.004, ULCI: 0.030 & Yes \\
$\mathrm{AM} \rightarrow \mathrm{LE} \rightarrow \mathrm{HS}$ & -0.09 & 0.749 & 0.454 & LLCI: -0.035, ULCI: 0.014 & No \\
$\mathrm{AM} \rightarrow \mathrm{AE} \rightarrow \mathrm{LE}$ & 0.070 & 2.674 & 0.007 & LLCI: 0.020, ULCI: 0.124 & Yes \\
\hline
\end{tabular}

Note: $\mathrm{AM}=$ Academic use of personal technology, $\mathrm{AE}=$ Active engagement in courses, $\mathrm{HS}=$ Higher-order thinking skills, LE= Learning effort; LLCI= lower level confidence interval; ULCI=upper level confidence interval.

\section{Discussion and Conclusions}

This study focuses on the influence of undergraduate students' academic use of mobile technology on their higher-order thinking skills through their active engagement and learning effort. Since students are increasingly using mobile technology for academic purposes, there is a need to understand the educational impact of this technology on students' university learning experiences. This study predicted that students' academic use of mobile technology in courses would be beneficial for their engagement and perceived higher-order thinking skills. The results of the PLS-SEM analysis support five of the six proposed hypotheses: $\mathrm{H} 1, \mathrm{H} 2, \mathrm{H} 4, \mathrm{H} 5$, and H6. Our findings reveal that the use of mobile technology for academic work supports the propositions of our research model regarding the mediation of students' active engagement in courses and learning effort. That is, students' academic use of mobile technology positively affects their perception of their higher-order thinking skills. Based on the empirical results, several key findings emerge.

First, the positive effect of the academic use of mobile technology on active engagement in courses can be interpreted as students using mobile technology to be engaged in active and collaborative learning with both other students and teachers during class, as well as to retrieve the learning references required to perform pre- and post-course tasks. This finding is in line with studies showing the positive impact of using mobile technology to engage in active learning during academic activities [2,84]. However, the use of technology in a course does not always guarantee a positive impact on learning and performance (e.g., [85,86]). Rashid and Asghar [16] explained that a negative relationship between technology use and academic performance may be triggered by the use of unreliable technology or by the excessively frequent use of technology, which can cause distractions and a shortage of time for academic tasks. The results of this study indicate that students who actively use mobile technology for academic work are likely to be highly engaged in class, because they are more prepared for class activities due to their purposeful and focused use of mobile technology.

Second, students' academic use of mobile technology is predictive of their higher-order thinking skills. According to Chan, Wan, and Ko [87], students' experience of active collaborative learning mediates the relationship between interaction through technology and learning performance. Students' perception of their higher-order thinking skills measures how much they have learned and cognitively grown through learning from their academic experiences. Growth in students' cognitive skills is facilitated by discussions with others, reflections on their knowledge and information, and application 
of knowledge to deepen their learning experiences [88]. Poorly designed or surface approaches of academic mobile technology use are not effectively connected with learning outcomes, particularly higher-order thinking skills. From this perspective, it is meaningful when they actively engage in class activities through appropriate facilitation by instructors and peer interactions for collective engagement.

Third, the academic use of mobile technology did not predict learning effort in our model; however, learning effort significantly predicted higher-order thinking skills. The result of $\mathrm{H} 3$ regarding the non-significant association between academic use of mobile technology and learning effort considers students' perceptions of using technology on effective learning when they are performing pre- and post-work for courses. This result implies that students may not strongly perceive the academic use of technology as learning behavior. Thus, it may be necessary to examine the circumstances governing students' perception of the academic use of mobile technology as spending time in learning or making an effort to improve their academic outcomes. Nevertheless, learning with technology can enhance students' academic motivation and increase their interest in academic work. Although learning effort did not fully mediate the relationship between the academic use of mobile technology and higher-order thinking skills, we found that students' learning effort impacts their perceived skills. This leads them to spend more time on learning. However, some argue that one should be cautious about technology in courses, as it may be disruptive or distracting and may consequently pose a threat to both students and faculty members [16].

The findings provide practical implications for educators in higher education. Advanced learning outcomes (e.g., higher-order thinking skills) are required for students to be actively engaged in the course. Mobile technology can be an effective and practical tool to facilitate engagement. It is not sufficient to encourage students to use technology. Educators must reconsider their approach and increase their instructional adoption of mobile technology, because many studies have revealed that it can provide enriched experiences, which consequently leads to educational success. As discussed, students have widely adopted mobile technology for their own purposes across formal and informal learning settings through supporting university BYOD strategies [89]. However, the BYOD strategy does not always guarantee positive learning outcomes such as students' cognitive growth. The effective use of mobile technology for students relies on well-designed learning activities, which can foster active engagement of students in communicating and collaborating with their peers and instructors. The instructor also plays a critical role in orchestrating the integration of mobile technology, content, and learning outcomes [90]. Instructors must adequately integrate technology into courses to achieve learning goals such as making students reflect, think critically, discuss actively, and combine opinions and information. They need to know how to operationalize the integration of mobile technology into their classrooms and how to operate devices effectively. Additionally, they need to assist students in adopting the technology.

This study also has several limitations, especially in its methodology. First, this study is limited in its sampling and the representativeness of its sample in terms of applying the survey method and selection of respondents, respectively. Even though we attempted to collect the sample with careful consideration of the demographic composition of Korean college students, we only included subjects who volunteered, since respondents were recruited through campus email. Therefore, there remains a possibility of coverage and sampling errors. Second, the data were collected through self-reports. The results might thus be particularly inadequate for cognitive measure or performance. Future studies should therefore assess participants' cognitive measures. Additionally, care must be exercised in interpreting the results based on exploratory discussion and views rather than making excessive generalizations. This limitation can be overcome by follow-up research that considers the characteristics of the student sample.

In conclusion, college students' academic use of mobile technology can positively predict their higher-order thinking skills either directly or indirectly through their active engagement in courses and learning effort. In the model, structural factors were found to play a significant role, emphasizing that the mobile technology incorporated into courses should include the meditation variables to 
provide better learning experiences. This finding can help educators design courses that facilitate the achievement of learning outcomes through the use of mobile devices.

Author Contributions: H.J.K. and P.Y. conceived the research idea and designed the research framework. H.J.K., P.Y., and J.I.H. co-wrote the original draft. J.I.H. provided additional ideas and background context. All three authors reviewed the final manuscript. All authors have read and agreed to the published version of the manuscript.

Funding: This research was supported by the Ministry of Education of the Republic of Korea and the National Research Foundation of Korea (NRF-2017S1A3A2066878).

Conflicts of Interest: The authors declare no conflicts of interest.

\section{References}

1. Han, I.; Shin, W.S. The use of a mobile learning management system and academic achievement of online students. Comput. Educ. 2016, 102, 79-89. [CrossRef]

2. Fu, Q.K.; Hwang, G.J. Trends in mobile technology-supported collaborative learning: A systematic review of journal publications from 2007 to 2016. Comput. Educ. 2018, 119, 129-143.

3. Morris, N.P.; Lambe, J.; Ciccone, J.; Swinnerton, B. Mobile technology: Students perceived benefits of apps for learning neuroanatomy. J. Comput. Assist. Learn. 2016, 32, 430-442. [CrossRef]

4. Shamir-Inbal, T.; Blau, I. Developing digital wisdom by students and teachers: The impact of integrating tablet computers on learning and pedagogy in an elementary school. J. Educ. Comput. Res. 2016, 54, 967-996.

5. Uzun, A.M.; Kilis, S. Does persistent involvement in media and technology lead to lower academic performance? Evaluating media and technology use in relation to multitasking, self-regulation and academic performance. Comput. Human. Behav. 2019, 90, 196-203.

6. Schmid, R.; Petko, D. Does the use of educational technology in personalized learning environments correlate with self-reported digital skills and beliefs of secondary-school students? Comput. Educ. 2019, 136, 75-86. [CrossRef]

7. Williams, K.M.; Stafford, R.E.; Corliss, S.B.; Reilly, E.D. Examining student characteristics, goals, and engagement in Massive Open Online Courses. Comput. Educ. 2018, 126, 433-442.

8. Johnson, L.; Adams Becker, S.; Cummins, M.; Estrada, V.; Freeman, A.; Ludgate, H. NMC Horizon Report: 2013 Higher Education Edition; The New Media Consortium: Austin, TX, USA, 2013.

9. Woodcock, B.; Middleton, A.; Nortcliffe, A. Considering the smartphone learner: An investigation into student interest in the use of personal technology to enhance their learning. Stud. Engagem. Exp. J. 2012, 1, 1-15.

10. Sánchez-Prieto, J.C.; Hernández-García, Á.; García-Peñalvo, F.J.; Chaparro-Peláez, J.; Olmos-Migueláñez, S. Break the walls! Second-order barriers and the acceptance of mLearning by first-year pre-service teachers. Comput. Human. Behav. 2019, 95, 158-167. [CrossRef]

11. Burden, K.; Kearney, M.; Schuck, S.; Hall, T. Investigating the use of innovative mobile pedagogies for school-aged students: A systematic literature review. Comput. Educ. 2019, 138, 83-100. [CrossRef]

12. Chen, F.; Sager, J. The effects of tablet PC use in the classroom on teaching and learning processes. J. Learn. High. Educ. 2011, 7, 55-67.

13. Negahban, A.; Chung, C.H. Discovering determinants of users perception of mobile device functionality fit. Comput. Human. Behav. 2014, 35, 75-84. [CrossRef]

14. Beetham, H.; Sharpe, R. Rethinking Pedagogy for a Digital Age: Designing for 21st Century Learning: Rethinking Pedagogy for a Digital Age, 2nd ed.; Routledge: New York, NY, USA, 2013.

15. Tapscott, D. Grown up Digital: How the Net Generation is Changing Your World; McGraw-Hill: New York, NY, USA, 2009.

16. Rashid, T.; Asghar, H.M. Technology use, self-directed learning, student engagement and academic performance: Examining the interrelations. Comput. Human. Behav. 2016, 63, 604-612. [CrossRef]

17. Kearney, M.; Schuck, S.; Burden, K.; Aubusson, P. Viewing mobile learning from a pedagogical perspective. Res. Learn. Technol. 2012, 20. [CrossRef]

18. O'Bannon, B.W.; Thomas, K. Teacher perceptions of using mobile phones in the classroom: Age matters! Comput. Educ. 2014, 74, 15-25. [CrossRef] 
19. Fitch, J.L. Student feedback in the college classroom: A technology solution. Educ. Technol. Res. Dev. 2004, 52, 71-77. [CrossRef]

20. Barak, M.; Lipson, A.; Lerman, S. Wireless laptops as means for promoting active learning in large lecture halls. J. Res. Technol. Educ. 2006, 38, 245-263. [CrossRef]

21. Siegle, D.; Foster, T. Laptop computers and multimedia and presentation software: Their effects on student achievement in anatomy and physiology. J. Res. Technol. Educ. 2001, 34, $29-37$.

22. Yang, S.H. Exploring college students' attitudes and self-efficacy of mobile learning. Turk. Online J. Educ. Technol. 2012, 11, 148-154.

23. Velzen, J.V. Metacognitive Knowledge: Development, Application, and Improvement; Information Age Publishing: Charlotte, NC, USA, 2017.

24. Anderson, L.W.; Krathwohl, D.R. A Taxonomy for Learning, Teaching, and Assessing: A Revision of Bloom's Taxonomy of Educational Objectives; Addison Wesley Longman: New York, NY, USA, 2001.

25. Ramos, J.L.S.; Dolipas, B.B.; Villamor, B.B. Higher order thinking skills and academic performance in physics of college students: A regression analysis. Int. J. Innov. Interdiscip. Res. 2013, 4, 48-60.

26. Goodfellow, R.; Lea, M.R. Literacy in the Digital University: Critical Perspectives on Learning, Scholarship, and Technology; Routledge: London, UK, 2013.

27. Echenique, E.G.; Molías, L.M.; Bullen, M. Students in higher education: Social and academic uses of digital technology. Int. J. Educ. Technol. High. Educ. 2015, 12, 25-37.

28. Guzmán-Simón, F.; García-Jiménez, E.; López-Cobo, I. Undergraduate students' perspectives on digital competence and academic literacy in a Spanish University. Comput. Hum. Behav. 2017, 74, 196-204.

29. Margaryan, A.; Littlejohn, A.; Vojt, G. Are digital natives a myth or reality? University students' use of digital technologies. Comput. Educ. 2011, 56, 429-440. [CrossRef]

30. Kuh, G.D.; Vesper, N. Do computers enhance or detract from student learning? Res. High. Educ. 2001, 42, 87-102. [CrossRef]

31. Lee, J.; Choi, H. What affects learner's higher-order thinking in technology-enhanced learning environments? The effects of learner factors. Comput. Educ. 2017, 115, 143-152.

32. Schindler, L.A.; Burkholder, G.J.; Morad, O.A.; Marsh, C. Computer-based technology and student engagement: A critical review of the literature. Int. J. Educ. Technol. High. Educ. 2017, 14, 1-28.

33. Barak, M.; Dori, Y.J. Enhancing higher order thinking skills among inservice science teachers via embedded assessment. J. Sci. Teacher Educ. 2009, 20, 459-474. [CrossRef]

34. Barak, M.; Levenberg, A. Flexible thinking in learning: An individual differences measure for learning in technology-enhanced environments. Comput. Educ. 2016, 99, 39-52. [CrossRef]

35. Marra, R.; Palmer, B. Encouraging intellectual growth: Senior college student profiles. J. Adult Dev. 2004, 11, 111-122.

36. Pascarella, E.T.; Terenzini, P.T. How College Affects Students: A Third Decade of Research; Jossey-Bass: San Francisco, CA, USA, 2005.

37. Pike, G.R. Using college students' self-reported learning outcomes in scholarly research. New. Direct. Inst. Res. 2011, 41-58. [CrossRef]

38. Biggs, J.B. Student Approaches to Learning and Studying; Australian Education Research and Development: Hawthorn, VIC, Australia, 1987.

39. Laird, T.; Shoup, R.; Kuh, G. Deep Learning and College Outcomes: Do Fields of Study Differ? Annual Meeting of the Association for Institutional Research: San Diego, CA, USA, 2005.

40. Coates, H. Student Engagement in Campus-Based and Online Education: University Connections; Routledge: New York, NY, USA, 2006.

41. Cheng, M.T.; Lin, Y.W.; She, H.C. Learning through playing Virtual Age: Exploring the interactions among student concept learning, gaming performance, in-game behaviors, and the use of in-game characters. Comput. Educ. 2015, 86, 18-20.

42. Fonseca, D.; Martí, N.; Redondo, E.; Navarro, I.; Sánchez, A. Relationship between student profile, tool use, participation, and academic performance with the use of augmented reality technology for visualized architecture models. Comput. Human. Behav. 2014, 31, 434-445.

43. Crawford, C.M.; Smith, M.S. Rethinking Bloom's taxonomy: Implicit cognitive vulnerability as an impetus towards higher order thinking skills. In Exploring Implicit Cognition: Learning, Memory, and Social Cognitive Processes; IGI Global: Hershey, PA, USA, 2015; pp. 86-103. [CrossRef] 
44. Tendhar, C.; Culver, S.M.; Burge, P.L. Validating the National Survey of Student Engagement (NSSE) at a research-intensive university. J. Educ. Train. Stud. 2013, 1, 182-193.

45. Fensham, P.J.; Bellocchi, A. Higher order thinking in chemistry curriculum and its assessment. Think. Ski. Creat. 2013. [CrossRef]

46. Zohar, A.; Dori, Y.J. Higher order thinking skills and low-achieving students: Are they mutually exclusive? J. Learn. Sci. 2003, 12, 145-181. [CrossRef]

47. Atkinson, R.C.; Geiser, S. Reflections on a century of college admissions tests. Edu. Res. 2009, 38, 665-676.

48. Jerald, C.D. Defining a 21st Century Education; The Center for Public Education: Alexandria, VA, USA, 2009. Available online: http://citeseerx.ist.psu.edu/viewdoc/download?doi=10.1.1.460.8011\&rep=rep1\&type=pdf (accessed on 1 December 2019).

49. Erickson, B.; Peters, C.; Strommer, D. Teaching First-Year College Students; Jossey-Bass: San Francisco, CA, USA, 2006.

50. Song, Y. "Bring Your Own Device (BYOD)" for seamless science inquiry in a primary school. Comput. Educ. 2014, 74, 50-60.

51. Sung, Y.T.; Chang, K.E.; Liu, T.C. The effects of integrating mobile devices with teaching and learning on students' learning performance: A meta-analysis and research synthesis. Comput. Educ. 2016, 94, 252-275. [CrossRef]

52. Trimmel, M.; Bachmann, J. Cognitive, social, motivational and health aspects of students in laptop classrooms. J. Comput. Assist. Learn. 2004, 20, 151-158.

53. Ranieri, M.; Raffaghelli, J.E.; Bruni, I. Game-based student response system: Revisiting its potentials and criticalities in large-size classes. Act. Learn. High. Educ. 2018. [CrossRef]

54. Drain, T.S.; Grier, L.E.; Sun, W. Is the growing use of electronic devices beneficial to academic performance? Results from archival data and a survey. Issues Inf. Syst. 2012, 13, 225-231.

55. Carr, R.; Palmer, S.; Hagel, P. Active learning: The importance of developing a comprehensive measure. Act. Learn. High. Educ. 2015, 16, 173-186. [CrossRef]

56. Krause, K.-L.; Coates, H. Students' engagement in first-year university. Assess. Eval. High. Educ. 2008, 33, 493-505. [CrossRef]

57. Kuh, G.D. How to help students achieve. Chron. High. Educ. 2007, 53, 12-13.

58. Rau, W.; Durand, A. The academic ethic and college grades: Does hard work help students to "make the grade"? Sociol. Educ. 2000, 73, 19-38. [CrossRef]

59. Schuman, H.; Walsh, E.; Olson, C.; Etheridge, B. Effort and reward: The assumption that college grades are affected by quantity of study. Soc. Forces 1985, 63, 945-966. [CrossRef]

60. Williams, R. Higher-Order Thinking Skills: Challenging All Students to Achieve; Skyhorse Publishing: New York, NY, USA, 2015.

61. Kuh, G.D. What student affairs professionals need to know about student engagement. J. Coll. Stud. Dev. 2009, 50, 683-706. [CrossRef]

62. Richter, D.; Lehrl, S.; Weinert, S. Enjoyment of learning and learning effort in primary school: The significance of child individual characteristics and stimulation at home and at preschool. Early Child Dev. Care 2016, 186, 96-116. [CrossRef]

63. Franklin, M. The effects of differential college environments on academic learning and student perceptions of cognitive development. Res. High. Educ. 1995, 36, 127-153. [CrossRef]

64. Hoshower, L.; Chen, Y. Persuading students of their responsibilities in the learning process. Coll. Teach. Learn. 2005, 2, 7-16. [CrossRef]

65. Rodgers, T. Student engagement in the e-learning process and the impact on their grades. Int. J. Cyber Soc. Educ. 2008, 1, 143-156.

66. Plant, E.A.; Ericsson, K.A.; Hill, L.; Asberg, K. Why study time does not predict grade point average across college students: Implications of deliberate practice for academic performance. Contemp. Educ. Psychol. 2005, 30, 96-116. [CrossRef]

67. Heiphetz, A. How Mobile Technology can Enhance Student Learning and Workforce Training; McGraw-Hill: New York, NY, USA, 2011.

68. Kennedy, G.E.; Judd, T.S.; Churchward, A.; Gray, K.; Krause, K.L. First year students' experiences with technology: Are they really digital natives? Australas. J. Educ. Technol. 2008, 24, 108-122. [CrossRef] 
69. NSSE. Major Differences: Examining Student Engagement by Field of Study; NSSE Institute: Bloomington, IN, USA, 2010. Available online: https://nsse.indiana.edu/NSSE_2010_Results/pdf/NSSE_2010_AnnualResults.pdf (accessed on 1 December 2019).

70. Chin, W.W. The partial least squares approach to structural equation modeling. Mod. Methods Bus. Res. 1998, 295, 295-336.

71. Wold, H. Partial least squares. In Encyclopedia of Statistical Sciences; Kotz, S., Johnson, N.L., Eds.; Wiley: New York, NY, USA, 1985; pp. 581-591.

72. Hair, J.F.J.; Hult, G.T.M.; Ringle, C.; Sarstedt, M. A Primer on Partial Least Squares Structural Equation Modeling (PLS-SEM), 2nd ed.; Sage Publications: Thousand Oaks, CA, USA, 2016.

73. Ringle, C.M.; Wende, S.; Becker, J.-M. SmartPLS 3; SmartPLS GmbH: Boenningstedt, Germany, 2015.

74. Henseler, J.; Ringle, C.M.; Sinkovics, R.R. The use of partial least squares path modeling in international marketing. In Advances in International Marketing; Sinkovics, R.R., Ghauri, P.N., Eds.; Emerald: Bingley, UK, 2009; pp. 277-320.

75. Kroonenberg, P.M.; Lohmoller, J.-B. Latent Variable Path Modeling with Partial Least Squares; Phyica-Verlag HD: Heidelberg, Germany, 1989.

76. Churchill, G.C., Jr. A paradigm for developing better measures of marketing constructs. J. Mark. Res. 1979, 16, 64-73. [CrossRef]

77. Chin, W.W. How to write up and report PLS analyses. In Handbook of Partial Least Squares: Concepts, Methods, and Applications; Esposito Vinzi, V., Chin, W.W., Henseler, J., Wang, H., Eds.; Springer: Berlin/Heidelberg, Germany, 2010; pp. 655-690.

78. Kerlinger, F.N.; Lee, H.B. Foundations of Behavioral Research, 4th ed.; Harcourt College Publishers: New York, NY, USA, 2000.

79. Fornell, C.; Larcker, D.F. Evaluating structural equation models with unobservable variables and measurement error. J. Mark. Res. 1981, 18, 39-50. [CrossRef]

80. Tenenhaus, M.; Vinzi, V.E.; Chatelin, Y.M.; Lauro, C. PLS path modeling. Comput. Stat. Data Anal. 2005, 48, 159-205. [CrossRef]

81. Nitzl, C.; Roldan, J.L.; Cepeda, G. Mediation analysis in partial least squares path modelling, Helping researchers discuss more sophisticated models. Ind. Manag. Data Syst. 2016, 116, 1849-1864. [CrossRef]

82. Streukens, S.; Leroi-Werelds, S. Bootstrapping and PLS-SEM: A step-by-step guide to get more out of your bootstrap results. Eur. Manag. J. 2016, 34, 618-632. [CrossRef]

83. Hayes, A. Introduction to Mediation, Moderation, and Conditional Process Analysis; Guilford: New York, NY, USA, 2013.

84. Scornavacca, E.; Huff, S.; Marshall, S. Mobile phones in the classroom: If you can't beat them, join them. Commun. ACM 2009, 52, 142-146. [CrossRef]

85. Chen, Y.F.; Peng, S.S. University students' internet use and its relationships with academic performance, interpersonal relationships, psychosocial adjustment, and self-evaluation. Cyberpsychol. Behav. 2008, 11, 467-469. [CrossRef] [PubMed]

86. Sana, F.; Weston, T.; Cepeda, N.J. Laptop multitasking hinders classroom learning for both users and nearby peers. Comput. Educ. 2013, 24-31.

87. Chan, S.C.H.; Wan, J.C.L.; Ko, S. Interactivity, active collaborative learning, and learning performance: The moderating role of perceived fun by using personal response systems. Int. J. Manag. Educ. 2019, 17, 94-102. [CrossRef]

88. Biggs, J.B. Approaches to the enhancement of tertiary teaching. High. Educ. Res. Dev. 1989, 8, 7-26. [CrossRef]

89. Kobus, M.B.W.; Rietveld, P.; Van Ommeren, J.N. Ownership versus on-campus use of mobile IT devices by university students. Comput. Educ. 2013, 68, 29-41. [CrossRef]

90. Sharples, M.; Scanlon, E.; Ainsworth, S.; Anastopoulou, S.; Collins, T.; Crook, C.; Jones, A.; Kerawalla, L.; Littleton, K.; Mulholland, P.; et al. Personal inquiry: Orchestrating science investigations within and beyond the classroom. J. Learn. Sci. 2015, 24, 308-341. [CrossRef]

(C) 2020 by the authors. Licensee MDPI, Basel, Switzerland. This article is an open access article distributed under the terms and conditions of the Creative Commons Attribution (CC BY) license (http://creativecommons.org/licenses/by/4.0/). 